\title{
Relationship between Parent's Drug Use, Peer Group Influence and Adolescents' Addictive Behaviour
}

\author{
Onukwufor, Jonathan N. PhD \\ Department of Educational Psychology, Guidance and Counseling, University of Port Harcourt, \\ Rivers State, Nigeria \\ onukwuforjonathan@yahoo.com \\ Echendu, Ihedi Ogide \\ Department of Educational Psychology, Guidance and Counseling, University of Port Harcourt, \\ Rivers State, Nigeria. \\ ihediechendu@gmail.com
}

\begin{abstract}
This study examined the relationship between parents drug use, peer group influence and adolescents' addictive behaviour in Ahoada East and Ahoada West Local Government Areas of Rivers State. The population of the study comprised all Senior Secondary School Students in class one (SSI) in Ahoada East and Ahoada West L.G.A. The population of the study is 2963 (Ahoada East 1559; Ahoada West 1404) as at the time of this study. The sample of the study was 408 SS1 students who were sampled using purposive sampling technique and ex-post facto research design. Two instruments 'adolescent addictive behaviour checklist' $(A A B C)$ and 'adolescent reasons for drug taking inventory' (RDTI) with 30 items each and a reliability coefficient of 0.82 for 'AABC' and 0.78 for 'RDTI' were used for the study. Two research questions and two hypotheses were formulated to guide the study, and the statistical tools for data analysis was pearson product moment correlation coefficient for research questions and regression analysis was used in testing hypotheses at 0.05 level of significance. Findings reveal a high significant relationship between parents drug use and adolescent addictive behaviour. Also peer group influence and adolescents' addictive behaviour have a significant positive relationship. It was recommended that parents should be careful on the kind of behaviour they exhibit before their children and the adolescents should be guided in their choice offriends and associates.
\end{abstract}

Keywords : Parents'drug use, addictive behaviour and peer group influence

\section{INTRODUCTION}

Adolescence is a universal phenomenon and includes behavioural, social and emotional changes in adolescents'. Adolescence is the span of years between childhood and adulthood. In Nigeria, adolescence begins at about age twelve or thirteen and ends at either the late teens or early twenties (Eriega, 2006).

O'Donoghue and Robin in Berger (2005:339) stated that:

"Adolescence period is characterized by rapid physical, biological, cognitive and psychosocial change in the physical and biologic development, adolescents experience rapid physical growth such as: increase in height, weight, size, body configuration, appearance of primary and secondary sex characteristics such as enlargement of breast in girls, growth of pubic hairs in both boys and girls, and appearance of menarche in girls. Cognitively, adolescents experience a more complex mental activities such as abstract and hypothetical reasoning, intellectually curious about themselves and the world, develop better understanding of personal abilities, have a wide range of intellectual pursuits, prefer active over passive learning experiences and prefer interaction with peers during learning activities. Adolescents are intensely curious and inquisitive about adults, often challenging their authority; respond positively to opportunities to participate in real life situations. Psychosocially, adolescents experience such characteristics as mood swings, increasingly concerned about peer acceptance, strong need to belong to a group, experiment with new slang and behaviour as they search for a social position within their group, exhibit 
unpredictability release excess energy often resulting in sudden and apparently meaningless outburst of activity."

Adolescents are centrally characterized by change. The change is from childhood to adulthood as well as the transition from dependence to relative socio-economic independence. Addictive behaviour as defined by Pomerleau and Pomerleau in Peele (1988:12) "is the repeated use of a substance and or a compelling involvement in a behaviour that directly or indirectly modifies the internal milieu as indicated by changes in neur-chemical and neuronal activities in such a way as to produce immediate reinforcement but whose long term effect are personally or medically harmful or highly disadvantageous socially". This indicates strength of behaviour and compulsion as critical criterion for addictive behaviour.

Addictive behaviour is the compulsive or obsessive indulgence of an adolescent to psychoactive substances, objects, and activities despite the harmful effects of such. Engs (1996:13) defined addictive behaviour as "an activity, substance, object, or behaviour that has become the major focus of a person's life to the exclusion of other activities, or that has begun to harm the individuals or others physically, mentally or socially.

An individual can become addicted to anything. This has led to the assertion that there are similarities between physical dependence to various psycho-active substances such as alcohol and heroin and psychological dependence such as compulsive gambling, sex, exercise or eating. Adolescents' addictive behaviours could be derived from their physiological, psychological and psychosocial experiences in growth and developmental process. These experiences ignite behavioural reactions which might result in addiction.

Iruloh and Amadi (2008) identified parents' drug use as related to adolescents' addictive behaviours. Substance use by parents include: cocaine, heroin, alcohol etc has been found to be associated with adolescents' addictive behaviour. Farrington Loeber, Stouthamer-Lober and Van Kammen (1998) found in their study of over 5,600 males that maternal cigarette smoking during pregnancy double the risk of addictive behaviour in adolescents.

Parental factors according to Iruloh and Amadi (2008) are essentially the relationship patterns which exist between parents and children. Parental factors exert significant impact on the overall development of the child. They identified parents' use of drugs, as related to adolescent addictive behaviour. Rothbaum and Weisz (1994) in their study found that the strength of association between parent drug use and adolescents' addiction was greater when measured by observation or interview. The peer group according to Santrock (2005) are children or adolescents who are about the same age or maturity level. Okujagu (1993) states that the peer group are usually children who are equal in terms of age. The peer group establishes their norms, standard of thought and behaviour to be pursued by its members. Consequently, the peer group may exert so much influence on adolescents substance or process addiction. Also adolescents' addictive behaviour brings acknowledgement and respect from peers. Adolescents' especially those who are weak socially may choose drug abuse as a means to integrate in a peer group and thereby increase self-esteem and decrease anxiety.

Stabenau (1989) reporting the investigation of Cloninger and Reich in which they used the family history diagnostic criteria (FHDC) with 210 as sample. They investigated the role of biological traits (genes) in patterns of addiction. The results show that $81 \%$ reported parent or sibling was alcoholic by family history. The study also compared those with alcoholism and those without alcoholism in their families. Findings show that those with alcoholism in their families experience significantly more impaired control over their drinking behaviour with physical, pathologic and chronic alcoholic use than those without alcoholism in their family.

The National Association for children of alcoholics report (2002) reveal that children exposed parentally to illicit drugs are 2 to 3 times more likely to be abused or neglected. Also $79 \%$ of adolescents' runaway and homeless youth reported alcohol use in the home; 35\% reported problem drinking in the home. Likewise these adolescents because their parents use drugs and are exposed to substances exhibit depression and depressive symptoms more frequently than do adolescents from non-addictive parents.

Moss, Vanyukuv, Majumder, Kirisci and Tarter (1995) examined psychopathology amongst adolescents whose parents are substance abusers. Their findings reveal that boys whose fathers 
overcame drug use disorder prior to the child's school age period were similar to a control group of boys whose fathers had no drug use disorder. Conversely, boys whose fathers had continuing drug use disorder exhibited significant psychopathology. The investigation further provided evidence of Parents' drug use and other psychopathology may affect the development of their offspring through several mechanisms for example, parenting behaviours. Parental mental disorders may act as barriers impeding their children access to adequate mental health treatment, which in turn may increase the children's likelihood of developing addiction in adolescence.

Santrock (2005) citing Diehman et al, who examined peer influence and exposure to addiction. The findings revealed that adolescents exposure to peer use and misuse of substances along with susceptibility to peer pressure were strong predictors of adolescents addictive behaviour. The results also show the role of age in drug addiction among peer group members (same age, older or younger). Younger adolescents who use drugs were more likely to have older friends than those who did not.

Similarly, Kandel (1996) stated that adolescents involvement with delinquent peer group is related to the onset, frequency, and severity of adolescent delinquent behaviour such as substance use. Consequently, adolescent identification with delinquent peer group is one of the most important predicators of adolescent addiction.

Dishion and McMahon (1998) investigation on adolescent peer relation has indicated that children who become involved with delinquent peers are likely to start committing delinquent acts, and as the relationship bond gets stronger, a more intense and serious offending follows, skipping school, poor academic performance, maladjustment, teenage pregnancy and substance use or addiction.

Peer group influence has exhibited a synergetic relationship with adolescents' addictive behaviours. Thomberry and Krohn (1997) opined that affiliation to adolescents who are engaged in deviant behaviour whether it be theft, vandalism, violent behaviour, alcohol use or drug use represent the strongest predicator of adolescent addictive behaviour.

Fuligni, Eccles, Barber and Clement (2001) in their study on peer orientation and adolescent adjustment observed that extreme peer orientation had the most negative implication on adjustment. And this concept of extreme peer orientation defines adolescents as those who are willing to break their parents' rules and sacrifice important things in their lives in order to maintain contact with their peer and to preserve their popularity within the group.

They explained that peer orientation account for drug use among adolescents who relied more on peers than on their parents for advice and support. These adolescents are particularly sensitive to peer influence and are very concerned about peer acceptance and popularity and were particularly dependent on their age mates.

\subsection{Statement of the Problem}

Parents' drug use may expose the adolescent either by observation or modelling to the risk of developing addictive behaviour. Also peer influence may predispose the adolescent to involvement with substance use or abuse. Consequently, adolescents' addictive behaviour is a dangerous problem facing parents, teachers and society. Increasingly, adolescents are becoming addicted to psychoactive substances, thereby creating problems in the society which includes; arson, rape, armed robbery and murder. This study therefore found the relationship between parents' drug use, peer group influence and adolescents addictive behaviour.

\subsection{Aim of the Study}

The aim of this study was to examine whether there is any relationship between parents drug use, peer influence and adolescents' addiction. Specifically, the objectives are;

- To determine if parents drug use is related to adolescents' addiction.

- To ascertain if peer group influence is associated with adolescents' addictive behaviour.

\subsection{Research Question}

The following research questions were formulated to guide the study:

1. What is the relationship between parents' drug use and adolescents' addictive behaviour?

2. What is the relationship between peer group influence and adolescents' addictive behaviour? 


\subsection{Hypotheses}

The following null hypotheses were tested at 0.05 level of significance.

- There is no significant relationship between parents' drug use and adolescents' addictive behaviours.

- There is no significant relationship between peer group influence and adolescents' and addictive behaviour

\section{METHODOLOGY}

The study used the Ex-post Facto Design. The population of the study composed all senior secondary one students in Ahoada East and Ahoada West Local Government Areas. The population was made up of 2963 (Ahoada East - 1559, Ahoada West - 1404) as at the time of this study. Purposive sampling was used to draw 408 students (Ahoada East 230; Ahoada West 178) as sample for the study. The sample comprised 184 female and 224 males. Two instruments titled "Adolescent Addictive Behaviour Checklist" (AABC) and "Adolescent Reason for Drug Taking" (RDTI) were adapted from J.O. Akinboye's standardized test, titled "Adolescent Behaviour Assessment Battery" $(\mathrm{ABAB})$, to create addiction scales to represent the researchers construct of interest. Experts reevaluated the construct, face and content suitability of the instrument in obtaining relevant data. The validity and reliability of "AABC" and "RDTI" had a coefficient alpha of $\square=0.92$, the inventory was factor analyzed on factor 1 , which accounted for 24.00 discriminate constant validity was $r=0.86$, convergent constant validity $r=-0.85$, with Beck validity $r=0.70$.

The instruments consist of two sections, A and B. Section A was to elicit personal data of the students. Such as age, gender, class; Section B contained 30 items for each of the instruments measuring parents drug use and peer group influence. The instruments were modified to the Likert model in the response from the students. The research questions were answered using Pearson Product Moment Correlation. While the hypotheses were tested using regression analysis at 0.05 significance.

\section{Results}

Research Question 1: What is the relationship between parents' drug use and adolescents' addictive behaviours?

Hypothesis 1: There is no significant relationship between parents' drug use and adolescents' addictive behaviours.

Table1. Pearson Correlation of Parents' drug use and adolescent addictive behaviour

\begin{tabular}{|l|l|l|l|}
\hline & & $\begin{array}{l}\text { Adolescent addictive } \\
\text { Behaviour Checklist }\end{array}$ & Parental Drug Use \\
\hline Pearson Correlation & $\begin{array}{l}\text { Adolescent Addictive } \\
\text { Behaviour Checklist } \\
\text { Parental Drug Use }\end{array}$ & 1.000 & .716 \\
Sig. (2-tailed) & & .716 & 1,000 \\
$\mathrm{~N}$ & & 408 & 408 \\
\hline
\end{tabular}

Model Summary (b)

\begin{tabular}{|l|l|l|l|l|l|l|l|l|l|}
\hline & & & & & \multicolumn{3}{|c|}{ Change Statistics } \\
\hline Model & $\mathbf{R}$ & R-Square & $\begin{array}{l}\text { Adjusted } \\
\text { R-Square }\end{array}$ & $\begin{array}{l}\text { Std. Error of } \\
\text { the Estimate }\end{array}$ & $\begin{array}{l}\text { R-square } \\
\text { change }\end{array}$ & F Change & df1 df2 & Sig. CP \\
\hline 1 & $.716(\mathrm{a})$ & .512 & .511 & 5.85103 & .512 & 425.924 & 1 & 406 & 0.00 \\
\hline
\end{tabular}

a. Predictive (Constant) Parental Drug Use

b. Dependent Variable: Adolescent Addictive Behaviour

ANOVA (b)

\begin{tabular}{|l|l|l|l|l|l|}
\hline Model & Sum of square & Df & Mean square & F & Sig. \\
\hline 1 Pears on Correlation & 14581.328 & 1 & 14581.328 & 425.924 & $.000(\mathrm{a})$ \\
Residual & 13899.250 & 405 & 34.235 & & \\
$\mathrm{~N}$ & 28480.578 & 407 & & & \\
\hline
\end{tabular}

a. Predictive (Constant) Parental Drug Use

b. Dependent Variable: Adolescent Addictive Behaviour 


\section{Coefficients(s)}

\begin{tabular}{|l|l|l|l|l|l|l|}
\hline Model & \multicolumn{2}{|l|}{ Unstandar dized coefficient } & $\begin{array}{l}\text { Standardized } \\
\text { Coefficient }\end{array}$ & $\begin{array}{l}\text { Mean } \\
\text { square }\end{array}$ & $\mathbf{t}$ & $\begin{array}{l}\text { Sig. } \\
\text { Confidence }\end{array}$ \\
\hline & B & Std. Error & Betta & & & Lower bound \\
\hline 1 (Constant) & 27.3 .22 & 1.245 & .716 & 21.939 & .000 & 42.874 \\
Parental Drug Use & 2.456 & .329 & & 20.638 & .000 & 2.222 \\
\hline
\end{tabular}

Table 1, show that the relationship between parents drug use and adolescents addictive behaviour is 0.71 , this correlation coefficient show high positive relationship between parents drug use and adolescents additive behaviour.

The hypothesis is tested in table $1 \mathrm{~b}$ and using regression analysis. The regression analysis show that the correlation coefficient of $0.71 \%$ indicating the extent of relationship between parents drug use and adolescents addictive behaviours is significant. The F-ratio (425.924) is significant 0.01 and 0.05 level of significance. The Beta value show that parental drug use alone contributed $71.6 \%$ to the variation in adolescents addictive behaviours, since the regression analysis show F-ratio (435.924) which is higher than the critical value, (.512) the null hypothesis that "there is no significant relationship between parents drug use and adolescents' addictive behaviours" is rejected. The alternate hypothesis that 'there is significant relationship between parents' drug use and adolescents' addictive behaviours is accepted.

Research Question 2: What is the relationship between peer group influence and adolescents' addictive behaviours?

Hypothesis 2: There is no significant relationship between peer group influence and adolescents' addictive behaviours.

Table2. Pearson Correlation of Peer group Influence and Adolescent Addictive Behaviour

\begin{tabular}{|l|l|l|l|}
\hline & & $\begin{array}{l}\text { Adolescent addictive } \\
\text { Behaviour Checklist }\end{array}$ & Peer group influence \\
\hline Pig. (2-tailed) & $\begin{array}{l}\text { Adolescent Addictive } \\
\text { Behaviour Checklist Peer } \\
\text { Group Influence }\end{array}$ & 1.000 & .601 \\
$\mathrm{~N}$ & & .601 & 1,000 \\
\hline
\end{tabular}

Model Summary (b)

\begin{tabular}{|l|l|l|l|l|l|l|l|l|l|}
\hline & & & & & \multicolumn{3}{|c|}{ Change Statistics } \\
\hline Model & $\mathbf{R}$ & $\begin{array}{l}\text { R- } \\
\text { Square }\end{array}$ & $\begin{array}{l}\text { Adjusted } \\
\text { R-Square }\end{array}$ & $\begin{array}{l}\text { Std. Frror } \\
\text { of the } \\
\text { Estimate }\end{array}$ & $\begin{array}{l}\text { R-square } \\
\text { change }\end{array}$ & F Change & df1 & df2 & Sig. CP \\
\hline 1 & $.601(\mathrm{a})$ & .361 & .359 & 6.69694 & .361 & 229.032 & 1 & 406 & 0.00 \\
\hline
\end{tabular}

a. Predictive (Constant) Peer group influence

b. Dependent Variable: Adolescent Addictive Behaviour

ANOVA (b)

\begin{tabular}{|l|l|l|l|l|l|}
\hline Model & Sum of square & Df & Mean square & F & Sig. \\
\hline 1 Pears on Correlation & 10271.878 & 1 & 10271.878 & 229.032 & $.000(\mathrm{a})$ \\
& & & & & \\
\hline Residual & 18208.700 & 405 & 44.849 & & \\
\hline N & 28480.578 & 407 & & & \\
\hline
\end{tabular}

a. Predictive (Constant) Peer group influence

b. Dependent Variable: Adolescent Addictive Behaviour

\section{Coefficients(s)}

\begin{tabular}{|l|l|l|l|l|l|}
\hline Model & \multicolumn{2}{|l|}{ Unstandar dized coefficient } & $\begin{array}{l}\text { Standardized } \\
\text { Coefficient }\end{array}$ & t & Sig. Confidence \\
\hline & B & Std. Error & Betta & & Lower bound \\
\hline 1 (Constant) & 32.721 & 1.336 & .601 & 24.497 & .000 \\
Peer group influence & 2.113 & .140 & & 15.134 & .000 \\
\hline
\end{tabular}

a. Dependent variable Adolescent Addictive Behaviours 
Table 2 showed that the relationship between peer group influence and adolescents addictive behaviour is 0.60 , the coefficient correlation show high positive relationship between peer group influence and adolescents' addictive behaviour.

The hypothesis is analyzed in table $2 \mathrm{~b}$ using regression analysis. The regression analysis show that the correlation coefficient of $0.60 \%$, indicating the extent of relationship between peer group influence and adolescents addictive behaviours. The F-ratio (229.032) is significant at both 0.01 and 0.05 level of significance. The Beta value show that peer group influence alone contributed $60.1 \%$ to the variation in adolescents addictive behaviours. Since the regression analysis shows F-ratio (229.032) which is higher than the critical value (.361) the null hypothesis that "there is no significant relationship between peer group influence and adolescents addictive behaviours" is rejected. The alternate hypothesis that "there is significant relationship between peer group influence and adolescents addictive behaviours" is therefore accepted.

\section{SUMMARY OF RESULTS}

The result of the research question 1 and hypothesis 1 shown in table 1 revealed that there is a high positive relationship (0.71) between parents' drug use and adolescents' addictive behaviour in Ahoada East and Ahoada West Local Government Areas of Rivers State. The positive relationship between parent drug use and adolescents addictive behaviour means that as scores on parent drug use increases, there is a corresponding increase in adolescents addictive behaviour scores, and vice versa. This means that adolescents who use drugs are likely to come from homes where parents also use drugs.

When regression analysis was applied, $r$-value of 0.71 was found to be statistically significant at 0.05 level of significance (Table 1). The result therefore is that there is a significant positive relationship between parents drug use and adolescents addictive behaviours. The finding of this study is in agreement with those of Iruloh and Amadi (2008) citing Foscroft and Lowe study on the relationship between adolescents perceived family environment to some aspects of their self reported use of assorted kinds of hard drug. According to Min Qi Wang, Fitzhugh, Westerfield, (1995) parental smoking behaviour had little effect on male adolescent smoking behaviour or addiction. In fact, the influence of parental smoking in adolescence was not significant at any age level from $14-18$ years. This may be due to the male adolescent gradual shift away from parents towards peers during adolescence.

There is high positive and significant relationship between peer group influence and adolescents addictive behaviour in Ahoada East and Ahoada West Local Government Areas of Rivers State.

The results of research question 2 and hypothesis 2 shown in Table 2 reveals that there is a high positive relationship between peer group influence and adolescents addictive behaviours. The high positive relationship between peer group influence and adolescents addictive behaviours means that adolescents who have friends that have high addictive behaviours are likely also to have addictive behaviours while adolescents whose friends scores very low on adolescents addictive behaviours are unlikely to score high on adolescents addictive behaviours. When the regression analysis was applied, $\mathrm{r}$ value of 0.60 was found to be statistically significant at 0.05 level of significance (regression analysis yielded an F-ratio of 229.032). The result therefore is that there is a significant positive relationship between peer group influence and adolescents' addictive behaviour in Ahoada East and Ahoada West Local Government Areas of Rivers State. Kandel (1996) found that adolescent involvement with delinquent peer group is related as the onset, frequency, and severity of adolescent delinquent behaviour such as substance use.

The finding of the present study is in agreement with those of Santrock (2005) citing Dielman et al who examined peer pressure and exposure to addiction involving one hundred and thirty five 13 to 17 . years old adolescents as sample. The findings reveal that adolescents exposure to peer use and misuse of substances along with susceptibility of peer pressure were strong predicators of adolescents addictive behaviour. Also, peer influence on adolescent addiction was found to be insignificant when members of the peer group are positively engaged in productive activities (Min Qi Wang, et al. 1995).

\section{IMPLICATION OF THE STUDY}

There is high and positive relationship between parents' drug use and adolescents addictive behaviours. The implication of this result is that what parents do impact either positively or negatively on the behaviours of adolescents. Parents have the responsibility of displaying good conduct for 
adolescents to emulate as an increase on parents drug use scores also result in corresponding increase in adolescents addictive behaviour.

There is high positive and significant relationship between peer group influence and adolescent addictive behaviour as revealed by this study. The implication to both adolescents and parents is that, the peer group establishes the norms, standard of thought and behaviours to be pursued by its members and exert so much influence on adolescent life style (Okujagu, 1993). The adolescents have the responsibility of choosing friends that will assist them to realize their visions and dreams in life. The role of parents here is not to choose friends for their adolescents but guide them properly in choosing other adolescents that share their vision and dreams with their children without necessarily applying undue pressure.

\section{RECOMMENDATIONS}

Based on the result on the positive relationship between parent drug use and peer group influence, it is recommended that:

- Parents should be careful on the kind of behaviours they exhibit to their children to forestall their adolescents from acquiring or learning negative behaviours such as addiction.

- Adolescents should be guided in their choice of friends. Adolescents should not be left entirely on their own in their choice of friends. Parents also have some role to play.

- Guidance and counselling services should be introduced in secondary schools in Ahoada East and Ahoada West Local Government Areas of Rivers State, with functional facilities for effective counselling service.

\section{CONCLUSION}

This paper examined the relationship between parents drug use and peer group influence on adolescents' addictive behaviour in Ahoada East and Ahoada West Local Government Areas of Rivers State. The adolescents addictive behaviour was found to have been influenced by both parents drug use and peer group. The implications of this finding and recommendations were given to stem the involvement of adolescents' in drug addiction.

\section{REFERENCES}

Berger, K.S. (2005). The developing person through the life span. $\left(6^{\text {th }}\right.$ teaching. New York Delhi, Kalyani Publishers.

Dishion, T.J. and McMahon R.J. (1989). Parental monitoring and the prevention of the child and adolescent problem behaviour. A conceptual and empirical formulation. Clinical, Child, Family psychology Review 1:61-75.

Engler, B. (1996). Aclohol and other drugs: self responsibility. Bloomington, Tichenor publishing company.

Engs, R.C. (1996). Alcohol and other drugs; self responsibility. Bloomington, Tichenor publishing company.

Eriega, E.G. (2006). Understanding developmental psychology. U.S.A. Academic Press Inc.

Farrington Loeber, Stouthamer-Lober and Van Kammen (1998). Self- reported delinquency and a combined delinquency seriousness scale based on boys, mothers and teachers: concurrent and predictive validity for African-American and Caucasians criminology, 34, 493.

Fuligni, Eccles, Barber and Clement (2001). Early adolescent peer orientation and adjustment during high school. Journal of Development Psychology 37:28-36.

Iruloh, B.N. and Amadi, G.N. (2008). Psychosocial perspective of drug abuse: prevention and treatment. Port Harcourt, University of Port Harcourt press.

Kandel, D.B. (1996). The parental and peer context of adolescent deviance. An alebra of interpersonal influences. Journal of Drug Issues 26:298-315.

Moss, H.B.; Vanyukov, M.; Majumdar, P.P.; Kirisci, L. \& Tarter, R.E. (1995). Pre-Pubertal Sons of Substance Abusers: influences of parental and Familial Substance Abuse on Behavioural Disposition. I.Q. and school achievement. Addictive Behaviour 20(3)345-358.

Min Qi Wang; Fitzhugh, E.C; Westerfield, C. R (1995). Family and Peer influences on smoking behaviour among American adolescent: An age trend. Journal of Adolescent Health, 16, 3, $200-$ 203. available at http://www.Elsevier.com. 
National association for children of alcoholics. (2000). Children of Addicted parents: Important Facts. Rockville MD. Available online at www.nancoa.org.

Okujagu, T.N. (1993). Sociological perspectives of education. Owerri, Totan Publishers.

Peele, S. (1988). Visions of addition, major contemporary perceptions. Lanharm, Levington books.

Rothbaum, F. and Weisz, J.R. (1994). Parental care giving and child externalizing behaviour in non clinical samples: a meta-analysis. Psychological Bulletin, 116,55-74.

Santrock, J.W. (2005). Adolescence. New York. McGraw Hill publishing company.

Stabenau, J.R (1989). Family pedigree studies of biological vulnerability to drug dependence: Journal of drug abuse vulnerability V. 10, No.1 pg.3-6 C.A. Rockville press.

Thomberry and Krohn (1997). Peers, drug use and delinquency. In stoff, D.M. Breiling, J. and Maser, J.D. (eds). Handbook of anti social behaviour, Wiley, New York.

\section{AUTHORS' BIOGRAPHY}

Onukwufor, Jonathan N. Ph.D, is a Senior Lecturer in the Department of Educational Psychology Guidance and Counselling, University of Port Harcourt. He is a member of the Nigerian Council of Educational Psychologists, member Nigerian Association of Educational Researchers and Evaluators and member Counselling Association of Nigeria. He hails from Itu, Ezinihitte L.G.A. Imo state, Nigeria.

Echendu, Ihe di Ogide, was a graduate assistant, Rivers State University of Education Port Harcourt; Counselling Psychologist, Rivers State Rehabilitation Center Okehi 2. He holds a Master degree in Educational Psychology from the University of Port Harcourt, Rivers State, Nigeria, and member council of Educational Psychologists. 